\title{
Influence of environmental factors on spectral characteristics of chromophoric dissolved organic matter (CDOM) in Inner Mongolia Plateau, China
}

\author{
Z. D. Wen ${ }^{1}$, K. S. Song ${ }^{1}$, Y. Zhao ${ }^{1}$, J. Du ${ }^{1}$, and J. H. Ma ${ }^{1,2}$ \\ ${ }^{1}$ Northeast Institute of Geography and Agroecology, CAS, Changchun, China \\ ${ }^{2}$ University of Chinese Academy of Sciences, Beijing, China \\ Correspondence to: K. S. Song (songks@neigae.ac.cn) \\ Received: 30 March 2015 - Published in Hydrol. Earth Syst. Sci. Discuss.: 22 June 2015 \\ Revised: 19 January 2016 - Accepted: 31 January 2016 - Published: 19 February 2016
}

\begin{abstract}
Spectral characteristics of chromophoric dissolved organic matter (CDOM) were examined in conjunction with environmental factors in the waters of rivers and terminal lakes within the Hulun Buir plateau, northeast China. Dissolved organic carbon (DOC), total nitrogen (TN), and total phosphorous (TP) were significantly higher in terminal lakes than rivers waters $(p<0.01)$. Principal component analysis (PCA) indicated that non-water light absorption and anthropogenic nutrient disturbances were the likely causes of the diversity of water quality parameters. CDOM absorption in river waters was significantly lower than terminal lakes. Analysis of the ratio of absorption at 250 to $365 \mathrm{~nm}$ $\left(E_{250: 365}\right)$, specific ultraviolet (UV) absorbance (SUVA 254$)$, and the spectral slope ratio $\left(S_{\mathrm{r}}\right)$ indicated that CDOM in river waters had higher aromaticity, molecular weight, and vascular plant contribution than in terminal lakes. Furthermore, results showed that DOC concentration, CDOM light absorption, and the proportion of autochthonous sources of CDOM in plateau waters were all higher than in other freshwater rivers reported in the literature. The strong evapoconcentration, intense ultraviolet irradiance, and landscape features of the Hulun Buir plateau may be responsible for the above phenomenon. Redundancy analysis (RDA) indicated that the environmental variables total suspended matter (TSM), TN, and electrical conductivity (EC) had a strong correlation with light absorption characteristics, followed by total dissolved solid (TDS) and chlorophyll $a$. In most sampling locations, CDOM was the dominant non-water lightabsorbing substance. Light absorption by non-algal particles often exceeded that by phytoplankton in the plateau waters.
\end{abstract}

Study of these optical-physicochemical correlations is helpful in the evaluation of the potential influence of water quality factors on non-water light absorption in cold plateau water environments. The construction of a correlation between DOC concentration and water quality factors may help contribute to regional estimates of carbon sources and fate for catchment carbon budget assessments.

\section{Introduction}

Chromophoric dissolved organic matter (CDOM) is the colored component of dissolved organic matter (DOM) in the natural waters environment. The rivers serve to connect the terrestrial cycling of carbon with the marine carbon cycle (Alvarez-Cobelas et al., 2012; Guo et al., 2012; Para et al., 2010). Terrestrial allochthonous inputs are the dominant CDOM source in aquatic ecosystems (Nelson and Siegel, 2013; Zhou et al., 2015). Phytoplankton excretion, zooplankton, and bacterial metabolism are the major autochthonous CDOM sources (Coble, 2007). As an important constituent of DOM, which is the largest reservoir of organic carbon on Earth, CDOM plays a vital role in the global carbon cycle (Gonnelli et al., 2013; Mopper and Kieber, 2002). CDOM is one of the major light-absorbing constituents in natural waters; it can absorb solar radiation in the ultraviolet (UV) and visible ranges of the light spectrum to shield biota from harmful UV radiation. As a consequence of its optical behavior, CDOM is also largely responsible for the bio-optical properties of natural water, and has a potential effect on the 
productivity of the water column (Organelli et al., 2014). The absorption characteristics of CDOM also influences the inversion accuracy of remote sensing of chlorophyll $a(\mathrm{chl} a)$ and other suspended solids (Siegel et al., 2005; Song et al., 2014).

Spectral analysis of CDOM (absorption and fluorescence) has been used to trace its origin, chemical composition, and photochemical reaction (Stedmon et al., 2000; Vodacek et al., 1997; Xie et al., 2014). Understanding the spectral characteristics of CDOM could help to understand DOM cycling in aquatic ecosystems. According to previous studies, the light absorption of CDOM often decreases in a near-exponential manner with increasing optical wavelength (Coble, 2007; Zhang et al., 2010). In order to characterize the properties of CDOM from absorption spectra, several spectral indices have been previously developed. The ratio of absorption at 250 to $365 \mathrm{~nm}\left(E_{250: 365}\right)$ is used to track changes in the size of DOM molecules (De Haan and De Boer, 1987); specific UV absorbance $\left(\mathrm{SUVA}_{254}\right)$ is found to have strong correlation with DOM aromaticity as measured by $\mathrm{C}$ nuclear magnetic resonance $\left({ }^{13} \mathrm{CNMR}\right)$ spectroscopy (Weishaar et al., 2003). Two optical parameters, the absorption coefficient at specific wavelengths $\lambda \mathrm{nm}\left(a_{\mathrm{CDOM}} \lambda\right)$ and CDOM spectral slopes $(S)$, are generally recognized proxies of CDOM concentration and molecular origin (Helms et al., 2008). Furthermore, $S$ may also correlate with the ratio of fulvic acid (FA) to humic acid (HA). In fact, the use of $S$ is dependent on the calculated wavelength intervals, and the ratio of the slope $\left(S_{\mathrm{r}}\right)$, as a dimensionless parameter, could avoid the limitations of spectral wavelength measurements (Helms et al., 2008; Spencer et al., 2012). The analysis of these spectral indices is therefore useful for understanding spatial and temporal CDOM variations in the aquatic environment.

Recent studies have proven that CDOM in aquatic ecosystems exerts an impact on ecosystem productivity, optical properties of water, and biochemical processes (Zhang et al., 2007). However, regional CDOM characteristics are still not thoroughly understood in diverse aquatic environments because of various physicochemical parameters of water (Findlay and Sinsabaugh, 2003). Many water quality parameters have been proposed to affect the temporal and spatial variation of CDOM, and some correlations among them have been established; a significant positive correlation was found between dissolved organic carbon (DOC) and CDOM absorption coefficients, and a series of different models were established based on this correlation in Lake Taihu (Zhang et al., 2007), the Yangtze River (Zhang et al., 2005), and six rivers in Georgia (Yacobi et al., 2003). CDOM strongly absorbs in the blue spectral region, which interferes with the determination of chl $a$ concentration by remote image sensing (Siegel et al., 2005), therefore the relationship between the spectral characteristics of CDOM with chl $a$ concentration has received widespread attention. A significant linear relationship between $a_{\mathrm{CDOM}}(300)$ and chl $a$ concentrations was identified in the central eastern Mediterranean Basin (Brac- chini et al., 2010), the Atlantic Ocean (Kitidis et al., 2006), and the Baltic Sea (Kowalczuk et al., 2006), but $a_{\mathrm{CDOM}}(440)$ was loosely related to pigment concentrations in the $0-400 \mathrm{~m}$ depth layer of the NW Mediterranean Sea (Organelli et al., 2014). Furthermore, the relationship between $a_{\mathrm{CDOM}}(\lambda)$ and other physicochemical parameters of water, such as total nitrogen (TN), total phosphorous (TP), salinity, and extracellular enzyme activities (Gonnelli et al., 2013; Kowalczuk et al., 2006; Niu et al., 2014; Phong et al., 2014), were all investigated in different aquatic environments. However, these studies reached different conclusions due to regional variations in water quality.

Studies published to date have focused on the relationship between CDOM properties and environmental factors; results indicate that salinity, solar radiation, and watershed characteristics all have important effects on CDOM optical properties (Graeber et al., 2012; Gueguen et al., 2011; Mavi et al., 2012; Song et al., 2013b). The properties of CDOM in plateau water at high altitude have attracted interest due to the unique natural environmental and climatic features of these waters. The DOM composition in two Tibetan alpine lakes showed a limited terrigenous DOM and exhibited a high biolability of DOC (Spencer et al., 2014). The analysis of CDOM parameters in three intermontane plateau rivers in the western USA indicated that autochthonous DOM or DOM derived from anthropogenic sources dominated the DOM pool (Spencer et al., 2012). However, the relationship between CDOM and environmental factors in plateaus area has been less well studied. Analysis of these opticalphysicochemical correlations is critical for understanding the source and distribution of CDOM in plateau water environments and evaluating the potential influence of water quality factors on non-water light absorption.

The Inner Mongolia Plateau in China is located in an arid and cold climate zone with sparse annual rainfall. The plateau is covered with numerous lakes surrounded by vast grasslands and forest. These lakes are located far away from the ocean and are supplied with water by precipitation and river runoff, and most of them are noncontributing lakes (Tao et al., 2015). The unique geographical environment and climatic factor in arid and cold plateau regions altered CDOM properties, when compared with the bulk of inland water. Moreover, over $80 \%$ of the lakes are saline, which allows higher carbon storage levels than freshwater lakes (Duarte et al., 2008; Song et al., 2013b). The plateau lakes therefore play an important role in global carbon balance estimation.

Based on the above studies, we address the following issues. (1) Do CDOM properties in this cold plateau region differ within the plains? Is this difference related to the water quality of the terminal lakes? (2) Under the unique climatic and hydrological conditions of the boreal plateau, what is the main non-water light absorption component in water? We expect that the information obtained in this study can answer all of these questions. Answers to these questions can enhance our understanding of the non-water light absorption charac- 
teristics of inland waters in arid and cold plateau regions. The results of CDOM source and component analysis are also helpful for carbon storage estimation in these catchments. The optical-physicochemical correlation analysis could contribute to an improved understanding and interpretation of satellite remote sensing imagery for this area.

\section{Material and methods}

\subsection{Study sites}

The Inner Mongolia autonomous region is located in the north of China with an area of about 1.18 million $\mathrm{km}^{2}$ $\left(37^{\circ} 24^{\prime}-53^{\circ} 23^{\prime} \mathrm{N}, 97^{\circ} 12^{\prime}-126^{\circ} 04^{\prime} \mathrm{E}\right)$. The average altitude of the whole region is over $1000 \mathrm{~m}$, and it is basically a plateau landform composed of the Hulun Buir, Xilingol, Ulanqab, Bayannur, Alxa, and Erdos plateaus. Rivers, lakes, reservoirs, and other surface water areas account for $0.8 \%$ of the whole area. All of the water samples collected were taken from the Hulun Buir plateau (Fig. 1). The Hulun Buir plateau is located in the northeast of the Inner Mongolia plateau, with the topography being high in the east and low in the west. The east side of the plateau is connected to Daxing' anling mountains, and the geology composition consists mainly of Paleozoic granite, Mesozoic andesite, quartz trachyte, and tuff. Most of the overlying rock has weathered away into loess. The central regions are undulating rolling plains, and are made up of loose river and lacustrine sedimentary sand. The western regions are mainly low hills composed of volcanics. The physicogeographical zone of the whole Hulun Buir plateau is divided into a chernozem zone with forest and steppe, and a chestnut earth zone with steppe. This plateau is characterized by a typical semi-humid and semiarid continental monsoon climate with intensive solar radiation throughout the year. The Hulun Buir plateau has distinct seasons with a dry spring, a hot and rainless summer, a windy and short autumn, and a cold dry winter (Zheng et al., 2015). Based on long-term meteorological data (19612010), the average annual temperature is $0.8^{\circ} \mathrm{C}$. The average annual wind speed is $3.5 \mathrm{~m} \mathrm{~s}^{-1}$. The average annual rainfall is $273.9 \mathrm{~mm}, 70-80 \%$ of which falls in May-August (Bai et al., 2008). There are greater than three-quarters of days each year with direct sunlight. In this area, the average sunlight per day is over $8.2 \mathrm{~h}$. The average annual evaporation is $1615.3 \mathrm{~mm}$, which is far greater than precipitation, resulting in water scarcity. The soils of the area are Mollisols, and the topography consists of gently rolling hills and tablelands.

The plateau is dotted with numerous lakes surrounded by vast grasslands and forests, and the two largest freshwater lakes (Hulun Lake and Buir Lake) of Inner Mongolia are located in this area. Most lakes in this area are inland terminal lakes. Several rivers flow through Hulun Buir plateau, including the Kerulen, Ergun, Wuerxun, Hailar, and Zhadun rivers. Wuerxun River originates from Buir Lake's northern shore,
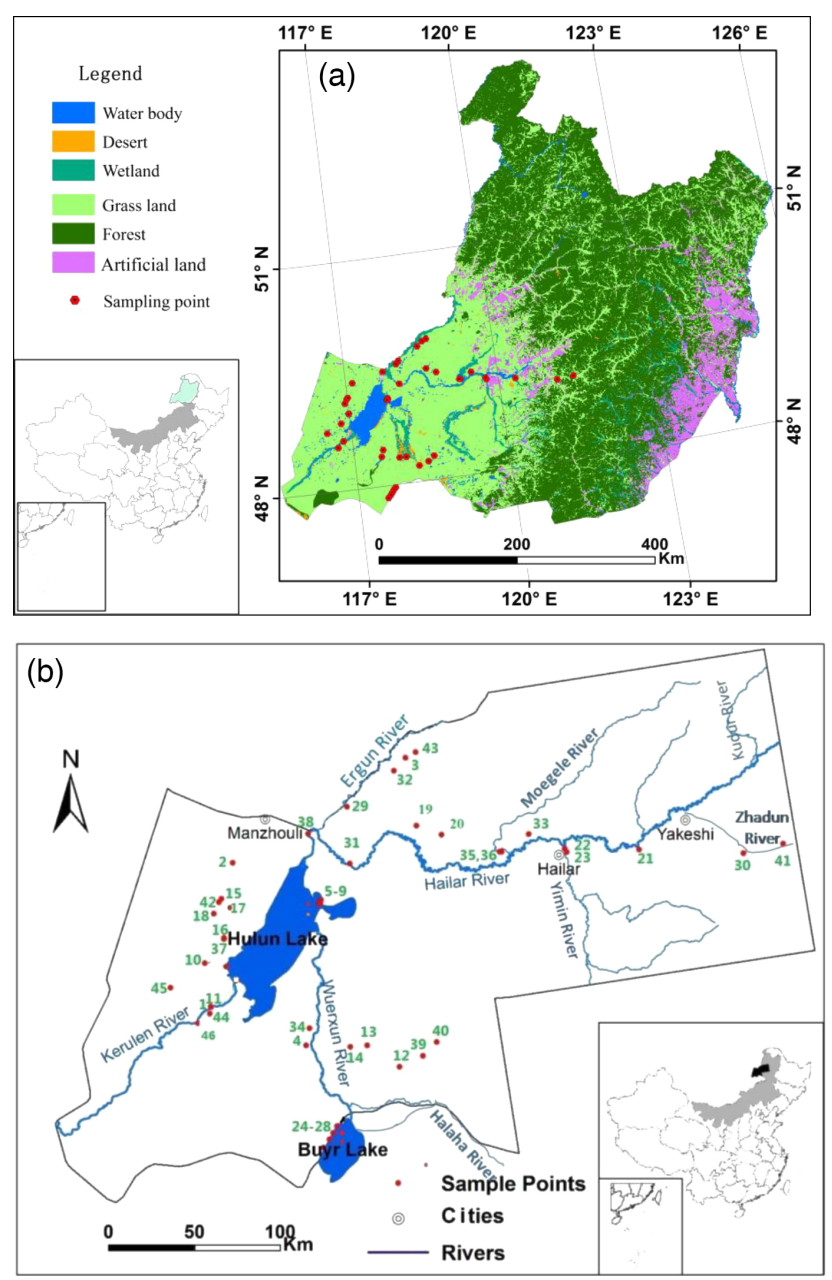

Figure 1. Study area location and sampling station distribution.

flows north, and empties into Hulun Lake. Kerulen River flows east through Hulun Lake, and finally into the Ergun River. The Zhadun River flows into the Hailar River, flowing north to join the Ergun River. A total of 46 surface waters were collected in this study with respect to both watershed characteristics and lake size.

\subsection{Water sampling and water quality measurement}

Water samples were taken from the Hulun Buir plateau, China, during September 2012 (Fig. 1), and the sampling numbers for each water body are listed in Table 1 and marked in Fig. 1. Based on the salinity and electrical conductivity $(\mathrm{EC})$ (salinity threshold value $=0.5 \mathrm{PSU}$, EC threshold value $=1000 \mathrm{~ms} \mathrm{~cm}^{-1}$ ), these waters were divided into 22 river waters and 24 saline waters. In particular, the saline waters were collected from lakes without outflow or the terminal flow of rivers. Hulun Lake and Buir Lake are connected with rivers, so the water samples collected from these lakes are classified as river water samples in the subsequent analysis in this study. The saline lakes' size in this study 
ranged from 1 to $42.5 \mathrm{~km}^{2}$, with an average depth of $0.4-$ $2.8 \mathrm{~m}$. The related hydrological data of rivers and freshwater lakes are shown in Table 2, including the names of rivers (or freshwater lakes), sampling numbers, basin area, width, length, maximum water depth, and elevation. The surface water $(0.5-1 \mathrm{~m})$ was collected in a sample bottle with at least $4 \mathrm{~L}$ in every sampling point, and kept in a portable refrigerator before they were returned to a laboratory. Chemical and physical parameters, e.g. $\mathrm{pH}$, total dissolved solid (TDS), and EC were determined by sampling in situ using a portable multi-parameter water quality analyzer (YSI6600, US). Concentrations of DOC, TN, and TP were measured with unfiltered water samples by a standard procedure (APHA/AWWA/WEF, 1998). Total suspended matter (TSM) was determined by gravimetrical analysis (Song et al., 2013a). Water turbidity was determined by a UV spectrophotometer in $680 \mathrm{~nm}$ (Shangfen, 7230) with Milli-Q water as a reference at room temperature $\left(20 \pm 2^{\circ}\right)$. Chlorophyll $a$ ( $\mathrm{chl} a$ ) was extracted from water samples by $90 \%$ buffered acetone solution, and the concentrations were determined with a UV spectrophotometer (Shimadzu, UV2600PC) by the method detailed in Song et al. (2013a).

\subsection{Non-water light absorption analysis}

CDOM was extracted from the water samples collected by filtering through a $0.7 \mu \mathrm{m}$ glass fiber membrane (Whatman, GF/F 1825-047) and then was further filtered through a $0.22 \mu \mathrm{m}$ polycarbonate membrane (Whatman, 110606). The filtering process was finished within 2 days in dim light in order to avoid alteration by microbial activity. Filtered samples were kept refrigerated and were warmed at room temperature at the time of the analysis. CDOM absorption was analyzed within $12 \mathrm{~h}$ using a UV-2600 spectrophotometer equipped with a $1 \mathrm{~cm}$ quartz cuvette. Absorbance scans were performed from 200 to $800 \mathrm{~nm}$, and Milli-Q water was used as a reference. Between each sample, the quartz cuvette was flushed with Milli-Q water, and the cleanliness was checked according to the optical density of reference water. Bubbles were avoided during the measurement. In order to eliminate the internal backscattering, the absorbance at $700 \mathrm{~nm}$ was used to correct absorption coefficients (Bricaud et al., 1981). The absorption coefficient $\left(a_{\mathrm{CDOM}}\right)$ was calculated from the measured water optical density (OD) following Eq. (1).

$a_{\mathrm{CDOM}}\left(\lambda^{\prime}\right)=2.303 \times \mathrm{OD} / L$,

where $L$ is the cuvette path length $(0.01 \mathrm{~m})$ and 2.303 is the conversion factor. $\mathrm{OD}_{\lambda}$ is the average optical density. The absorption coefficients at wavelengths $335 \mathrm{~nm}\left(a_{\mathrm{CDOM}} 335\right)$ and $440 \mathrm{~nm}\left(a_{\mathrm{CDOM}} 440\right)$ were selected to express the CDOM concentration (Miller, 1998). The CDOM absorption ratio $\left(E_{250: 365}\right)$ was calculated using absorbance at 250 and $365 \mathrm{~nm}$. SUVA 254 values were calculated by dividing the UV absorbance at $254 \mathrm{~nm}$ by the DOC concentration $\left(\mathrm{mg} \mathrm{L}^{-1}\right)$ (Weishaar et al., 2003).
CDOM spectral slopes $\left(S_{275-295}\right.$ and $\left.S_{350-400}\right)$ between wavelengths $275-295$ and $350-400 \mathrm{~nm}$ were both calculated using a nonlinear fit of an exponential function to the absorption spectrum according to Eq. (2) by Origin 8.0 software (Bricaud et al., 1981; Jerlov, 1968).

$a_{\mathrm{CDOM}}(\lambda)=a_{\mathrm{CDOM}}\left(\lambda_{0}\right) \times e^{S\left(\lambda_{0}-\lambda\right)}$,

where $a_{\mathrm{CDOM}}(\lambda)$ is the CDOM absorption at a given wavelength, and $a_{\mathrm{CDOM}}\left(\lambda_{0}\right)$ is the absorption at a reference wavelength $(440 \mathrm{~nm})$. The spectral slope ratio $\left(S_{\mathrm{r}}\right)$ was calculated as the ratio of $S_{275-295}$ to $S_{350-400}$.

Particulate absorption was determined by a quantitative membrane filter technique (Cleveland and Weidemann, 1993). A certain volume of water was filtered through a $0.7 \mu \mathrm{m}$ glass fiber membrane (Whatman, GF/F 1825-047), and the filter membrane was subsequently stored in the laboratory at $-80^{\circ}$ until analysis. The light absorption of total particulate trapped on the filter membrane was determined by UV spectrophotometry (Shimadzu, 2660) from 280 to $800 \mathrm{~nm}$ with a virgin wet membrane as a reference. After correction of the path length using the path length amplification factor $(\beta)$, the measured optical densities were transformed into total particulate absorption coefficients according to Eq. (3) (Bricaud and Stramski, 1990).

$a_{\mathrm{PB}}(\lambda)=2.303 \times \frac{S}{V} \times \mathrm{OD}_{\mathrm{S}}(\lambda)$,

where $a_{\mathrm{PB}}(\lambda)$ is the total particulate absorption at a given wavelength (nm), $S$ is the effective area of the deposited particle on the fiber membrane $\left(\mathrm{m}^{2}\right)$, and $V$ is the volume of the filtered water $\left(\mathrm{m}^{3}\right) . \mathrm{OD}(\lambda)$ is the optical density at the given wavelength $(\mathrm{nm})$.

The above fiber membranes loaded with total particulate were soaked in the sodium hypochlorite solution in order to remove the pigments, and the light absorption coefficient of non-algal particles $\left(a_{\mathrm{NAP}} \lambda\right)$ was determined and calculated as the $a_{\mathrm{PB}}(\lambda)$. The phytoplankton light absorption coefficient $\left(a_{\mathrm{phy}} \lambda\right)$ was the difference between $a_{\mathrm{PB}}(\lambda)$ and $a_{\mathrm{NAP}}(\lambda)$ according to Eq. (4).

$a_{\text {phy }}(\lambda)=a_{\mathrm{PB}}(\lambda)-a_{\mathrm{NAP}}(\lambda)$

\subsection{Statistical analysis}

The contributions of CDOM, phytoplankton, and non-algal particles (NAP) to non-water light absorption at $440 \mathrm{~nm}$ were calculated using Origin 8.0 software (Ortega-Retuerta et al., 2010). The variation of water quality parameters in different sampling locations was assessed by principal component analysis (PCA) using CANOCO 4.5 for Windows with centered and standardized variables. Correlations between water quality parameters and light absorption characteristics were determined by redundancy analysis (RDA) using CANOCO 4.5, light absorption characteristics were defined 
Table 1. Water quality and CDOM absorption parameters of water samples collected in the Hulun Buir plateau.

\begin{tabular}{llllll}
\hline & \multicolumn{2}{c}{ River water $(n=22)$} & & \multicolumn{2}{c}{ Terminal lakes $(n=24)$} \\
\cline { 2 - 3 } \cline { 5 - 6 } & Mean & Min-max & & Mean & Min-max \\
\hline DOC & $25.99 \pm 6.64$ & $8.44-39.74$ & & $83.83 \pm 68.79$ & $23.03-300.50$ \\
TN & $1.33 \pm 0.63$ & $0.64-3.51$ & & $4.58 \pm 3.80$ & $1.39-19.03$ \\
TP & $0.11 \pm 0.04$ & $0.06-0.23$ & & $1.52 \pm 1.87$ & $0.12-6.31$ \\
TAlk & $156.22 \pm 53.60$ & $48.00-298.56$ & & $652.70 \pm 642.15$ & $96.00-2906.40$ \\
EC & $325.95 \pm 141.64$ & $106.70-745.00$ & & $5729.69 \pm 9715.26$ & $1236-41000.00$ \\
TDS & $163.07 \pm 70.62$ & $53.40-372.00$ & & $743.59 \pm 483.34$ & $93.10-1505.00$ \\
Turbidity & $20.21 \pm 20.80$ & $2.19-83.84$ & & $273.79 \pm 608.75$ & $1.75-2521.20$ \\
Chl $a$ & $4.62 \pm 3.95$ & $0.04-11.06$ & & $6.27 \pm 11.06$ & $0-41.07$ \\
$a_{\text {CDOM }} 335$ & $18.29 \pm 9.87$ & $4.71-40.07$ & & $36.16 \pm 30.27$ & $10.47-158.24$ \\
$a_{\text {CDOM }} 440$ & $2.68 \pm 1.68$ & $0.60-7.14$ & & $5.60 \pm 5.10$ & $0.83-26.21$ \\
$E_{250: 365}$ & $7.80 \pm 2.30$ & $5.43-12.30$ & & $8.02 \pm 3.48$ & $5.47-20.73$ \\
SUVA & $2.74 \pm 1.08$ & $1.08-4.79$ & & $1.90 \pm 0.57$ & $0.79-3.74$ \\
$S_{275-295}$ & $0.019 \pm 0.004$ & $0.015-0.027$ & & $0.02 \pm 0.004$ & $0.015-0.031$ \\
$S_{\mathrm{R}}$ & $1.00 \pm 0.17$ & $0.73-1.35$ & & $1.05 \pm 0.09$ & $0.91-1.25$ \\
\hline
\end{tabular}

TN, TP, TDS, TSM, TAlk, and DOC represent total nitrogen, total phosphorus, total dissolved solids, total suspended matter, total alkalinity, and dissolved organic carbon concentration, respectively $\left(\mathrm{mg} \mathrm{L}^{-1}\right)$. EC represents the electrical conductivity of water samples $\left(\mu \mathrm{sm}^{-1}\right)$. Chl $a$ is chlorophyll $a$ concentration $(\mu \mathrm{g} \mathrm{L}-1)$. The unit of $\mathrm{SUVA}_{254}$ is $\mathrm{L} \mathrm{mg} \mathrm{C}^{-1} \mathrm{~m}^{-1}$. The unit of turbidity is NTU, nephelometric turbidity unit.

Table 2. Names of rivers (or freshwater lakes), sampling numbers, basin area, width, length, maximum water depth, and elevation in the Inner Mongolia Plateau.

\begin{tabular}{llrlrlrl}
\hline Name & Number & $\begin{array}{r}\text { Area } \\
\left(\mathrm{km}^{2}\right)\end{array}$ & $\begin{array}{l}\text { Max } \\
\text { depth } \\
(\mathrm{m})\end{array}$ & $\begin{array}{r}\text { Elevation } \\
(\mathrm{m})\end{array}$ & $\begin{array}{l}\text { Width } \\
(\mathrm{m})\end{array}$ & $\begin{array}{r}\text { Length } \\
(\mathrm{km})\end{array}$ & $\begin{array}{l}\text { Defined } \\
\text { type }\end{array}$ \\
\hline Kerulen River & 1,11 & 7153 & 1.9 & - & $60-70$ & 1264 & River \\
Hulun Lake & $5-9$ & 2339 & 33 & 545.9 & $30000-40000$ & - & River \\
Hailar River & 21,31 & 54500 & 1 & 1100 & $30-130$ & 1430 & River \\
Yimin River & $22-23$ & 22725 & 2.5 & - & $20-50$ & 390 & River \\
Buir Lake & $24-28$ & 609 & 21.6 & 583 & 20000 & - & River \\
Ergun River & 29 & 151184 & $>2$ & - & $200-300$ & 31966 & River \\
Moegele River & 36 & 150 & 2 & - & $1-6$ & River \\
Zhadun River & 30,41 & 3100 & 4 & 675 & $2-8$ & - & River \\
Wulannuor wetland & 34 & 710 & 3.5 & 540 & - & River \\
Qingkai River & 38 & - & 2 & 580 & $1-10$ & River \\
\hline
\end{tabular}

"-" denotes without data.

as species variables, and water quality parameters were selected as explanatory variables. The Pearson correlation coefficient $\left(r_{\mathrm{p}}\right)$ was calculated using SPSS 5.0. Because the responding variables may exist in the high autocorrelation, they were first screened through canonical correspondence analysis using CANOCO 4.5 to remove the variables with an inflation coefficient greater than 20 (Leps and Smilauer, 2003). A Monte Carlo permutation test was conducted with CANOCO 4.5 and indicated that the selected environmental variables were significantly related to light absorption characteristics (499 permutations under the reduced model, $p \leq 0.05$ ).

\section{Results}

\subsection{Water quality}

The collected river and terminal lake samples exhibited large variations in water quality (Table 1). A significant difference of DOC was also observed between these two water types $(p<0.001)$. The DOC concentration ranged from $8.44-39.74 \mathrm{mg} \mathrm{L}^{-1}$ in river waters, and exhibited higher values in the terminal lakes $\left(23.03-300.5 \mathrm{mg} \mathrm{L}^{-1}\right)$. Further, the terminal lakes also had higher alkalinity and EC than river waters. We have recalculated the statistics after log transformation of the data and a normal distribution test. A positive relationship between DOC and alkalinity was established in 

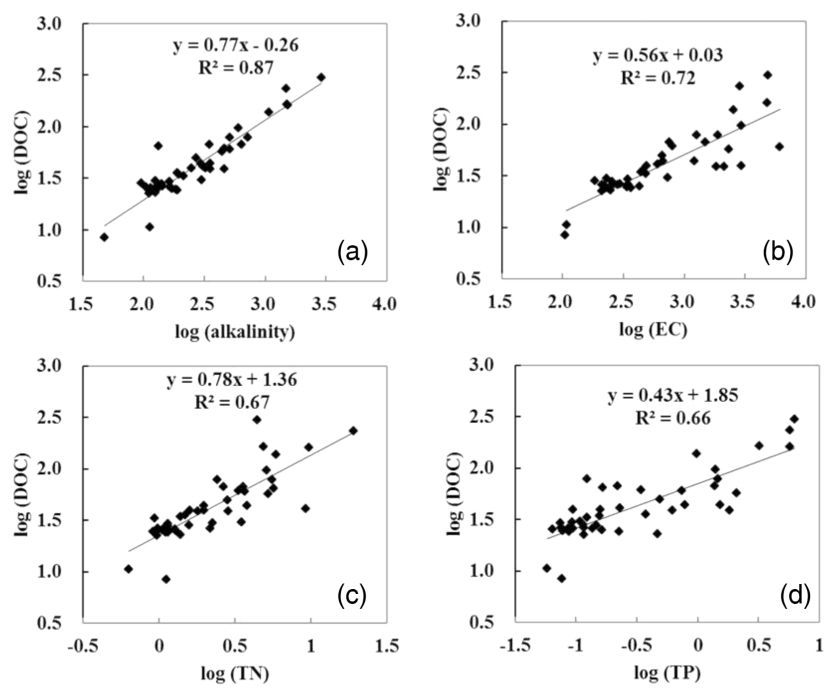

Figure 2. Correlation between DOC and alkalinity, EC, TN, and TP in Hulun Buir plateau water.

the Hulun Buir plateau waters (Fig. 2 a, $R^{2}=0.87$ ). Regression analyses were also conducted, and a linear relationship between EC and DOC was shown based on the collected data (Fig. $2 \mathrm{~b} ; R^{2}=0.72$ ). The average nutrient concentrations for TN $\left(1.33 \pm 0.63 \mathrm{mg} \mathrm{L}^{-1}\right)$ and TP $\left(0.11 \pm 0.04 \mathrm{mg} \mathrm{L}^{-1}\right)$ in river waters were both lower than in terminal lakes, and significant differences were observed for TN $(p<0.001)$ and TP $(p<0.01)$. Strong linear relationships were shown between TN and DOC in the Hulun Buir plateau (Fig. 2c; $\left.R^{2}=0.67\right)$. A positive correlation between DOC and TP was found in surface water in this area (Fig. $2 \mathrm{c} ; R^{2}=0.66$ ).

PCA was performed for all the sampling locations with 10 water environment variables (Fig. 3a). The first two principal components (PCs) of the PCA explained $61.0 \%$ of the variability in all the selected variables $(\mathrm{PC} 1,36.4 \%$; $\mathrm{PC} 2$, $24.6 \%$ ). Relatively high loadings on PC1 were TSM and turbidity, whereas DOC and CDOM showed high negative loadings. The second PCA axis revealed gradients of nutrients (TN and TP). These all had positive loadings on PC2. Furthermore, TDS and chl $a$ showed high negative loadings on PC2. A clear difference was found between river waters and terminal lakes (Fig. 3b). Terminal water samples clustered in close proximity to each other and were distributed on the negative side of PC2 (with the exception of one point) in Fig. 3b, and river waters clustered almost exclusively on the positive side of PC2.

\subsection{Spectral characteristics of CDOM}

CDOM absorption spectra of the waters collected from the Hulun Buir plateau decreased in a classical near-exponential manner, with increasing wavelengths from the ultraviolet to the visible spectral region. This near-exponential CDOM absorption spectra have been observed in many natural wa-
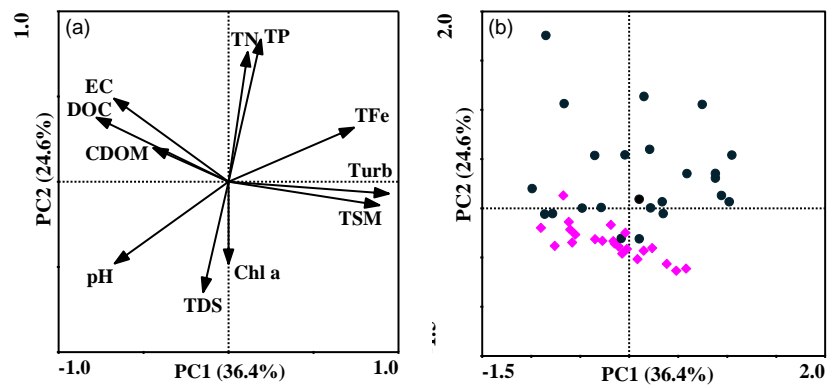

Figure 3. PCA of the physicochemical characteristics of all waters collected, (a) loading data of factors, and (b) sample scores. • represents terminal lakes, and $\downarrow$ represents river waters.

ters (Bricaud et al., 1981; Spencer et al., 2009; Xie et al., 2014). The comparative analysis was conducted in two types of sampling waters in the study, and the mean values of $a_{\mathrm{CDOM}}(335)$ and $a_{\mathrm{CDOM}}(440)$ both showed that the terminal lakes exhibited significantly higher CDOM light absorption than river waters (Table 1).

$E_{250: 365}$ values in the waters examined ranged from 5.43 to 20.73 , and the mean values were $7.80 \pm 2.30$ and $8.02 \pm 3.48$ in the river and terminal lakes respectively. The majority of the $\mathrm{SUVA}_{254}$ values in the river waters ranged from 1.09 to $3.56 \mathrm{~L} \mathrm{mg} \mathrm{C}^{-1} \mathrm{~m}^{-1}$, and the mean $\mathrm{SUVA}_{254}$ was clearly higher in river waters $\left(2.74 \pm 1.08 \mathrm{~L} \mathrm{mg} \mathrm{C}^{-1} \mathrm{~m}^{-1}\right)$ than the terminal lakes $\left(1.90 \pm 0.57 \mathrm{~L} \mathrm{mg} \mathrm{C}^{-1} \mathrm{~m}^{-1}\right)$, and this was significant $(p<0.01)$. In order to confirm the source and composition of CDOM in different types of waters, the spectral slopes in the $275-295 \mathrm{~nm}\left(S_{275-295}\right)$ and $350-400 \mathrm{~nm}\left(S_{350-400}\right)$ ranges were both calculated as the indicators (Table 1). $S_{275-295}$ values showed a wide variation in the river water samples, ranging from $14.80 \times 10^{-3}$ to $26.79 \times 10^{-3} \mathrm{~nm}^{-1}$ $\left(\right.$ mean $\left.=19.25 \pm 4.05 \times 10^{-3} \mathrm{~nm}^{-1}\right)$, and the majority of river waters in the study exhibited $S_{275-295}$ between 17.11 and $17.82 \times 10^{-3} \mathrm{~nm}^{-1}$. There was not a significant difference when compared with terminal lakes. $S_{350-400}$ values also showed no significant difference between the two types of waters. Furthermore, the mean values of $S_{275-295}$ and $S_{350-400}$ in Hulun Lake were both lower than Buir Lake.

\subsection{Light absorption of CDOM and particulates}

Detailed knowledge regarding the relative contributions of CDOM, phytoplankton, and non-algal particles to the total non-water light absorption is essential in bio-optical and biogeochemical models, and the relative contributions at $440 \mathrm{~nm}$ are shown in Fig. 4. There was no obvious difference in the relative contributions of CDOM, phytoplankton, and non-algal particles between river waters and terminal lakes $(p>0.5)$. At all the sampling locations, the mean contribution of CDOM to the total non-water light absorption was $52.78 \%$, with the range varying from 2.87 to $97.23 \%$, and 


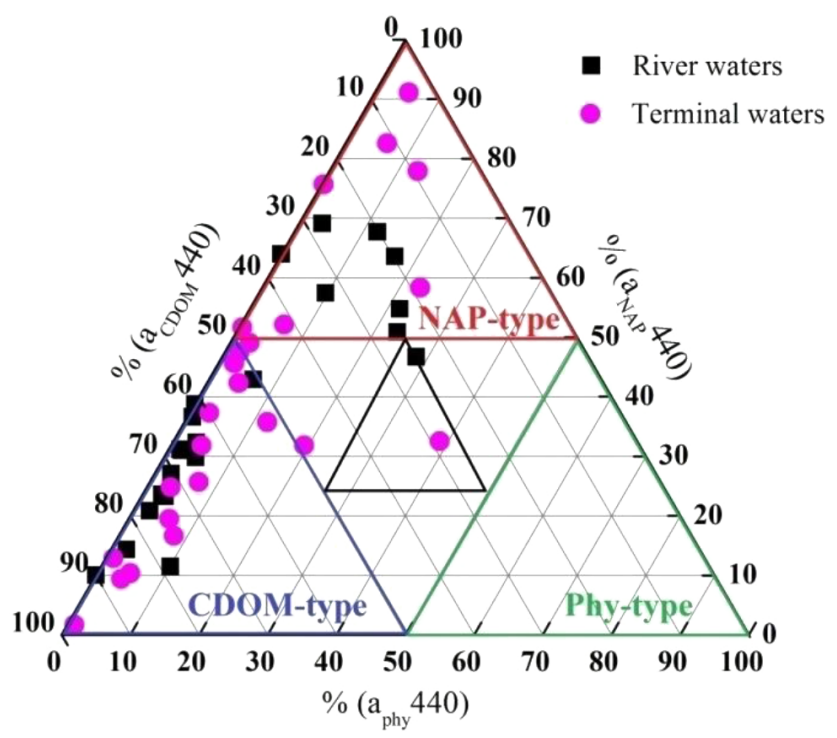

Figure 4. Relative contributions of CDOM, phytoplankton, and non-algal particles to total non-water light absorption at $440 \mathrm{~nm}$.

the relative contribution of non-algal particles was on average $39.84 \%$, ranging from $2.01 \%$ to $97.13 \%$. Phytoplankton absorption played a minor role in total non-water light absorption, with a mean of $7.61 \%$. In most water samples examined in this study, CDOM was the dominant non-water light-absorbing substance.

To assess the distribution of light absorption in the waters of the Hulun Buir plateau, levels of light absorption due to CDOM, phytoplankton, and non-algal particles were plotted based on the numbers of sampling locations and their contributions to total light absorption at $440 \mathrm{~nm}$ using a ParetoLorenz curve (Lorenz, 1905). The relative contributions were arranged from high to low. Subsequently, the cumulative sampling points are represented on the abscissa axis, and the cumulative contributions are plotted on the vertical axis. The more the curve deviated from the theoretical perfect evenness line ( $45^{\circ}$ diagonal), the more inhomogeneous light contributions were observed (Fig. 5). According to the Pareto principle, the value of the vertical axis was in accordance with $20 \%$ abscissa axis, which was used to interpret the ParetoLorenz curves. From the degree of curve deviation (Fig. 5), it was observed that the light absorption of optically active substances in the Hulun Buir plateau area presented inhomogeneous phenomena. Among them, CDOM absorption was the most representative relative to other non-water absorption components. CDOM light absorption by $20 \%$ of the samples corresponded with $5.03 \%$ of the cumulative CDOM contributions to non-water absorption. For non-algal particles and phytoplankton, $20 \%$ of the samples corresponded with 1.46 and $0.51 \%$ of cumulative light absorption contributions, respectively. Thus, for all the non-water absorption types, it was observed that CDOM light absorption was nu-

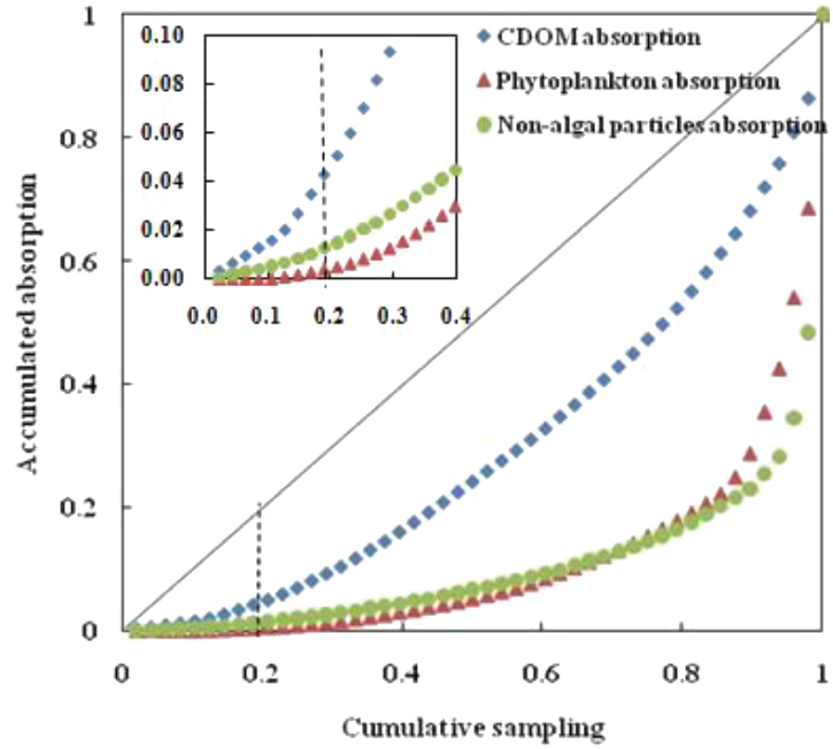

Figure 5. Pareto-Lorenz curves derived from the total non-water light absorption at $440 \mathrm{~nm}$.

merically dominant compared with non-algal particles and phytoplankton.

\subsection{Correlations between water quality parameters and light absorption}

The RDA data showed that the forward selected explanatory variables could explain the variability of light absorption characteristics with species-environment correlations of 0.781 (Fig. 6). The first two axes of RDA explained $43.7 \%$ of total variability in light absorption characteristics of all the water samples collected (axis one, $34.3 \%$; axis two, $9.4 \%$ ). Coefficients between environmental variables with axes in RDA indicated that TSM, TN, and EC had a strong correlation with light absorption characteristics, followed by TDS and chl $a$. TDS, TP, and DOC were most closely corrected to CDOM light absorption (Fig. 6). TSM, TN, and chl $a$ were best correlated to light absorption of phytoplankton, non-algal particulates, and total particulates at $440 \mathrm{~nm}$ (Fig. 6). EC and pH were related to the CDOM spectral slope $\left(S_{275-295)}\right.$ (Fig. 6).

The Pearson correlation coefficients $\left(r_{\mathrm{p}}\right)$ between water quality and light absorption characteristics presented in $\mathrm{Ta}-$ ble 3 indicate that CDOM light absorption $\left(\alpha_{\mathrm{CDOM}} 335\right.$ and $\left.\alpha_{\mathrm{CDOM}} 440\right)$ showed a significantly positive correlation with TN, TP, TDS, and DOC $(p<0.01)$, but had no correlation with chl $a$ concentration ( $p>0.05, n=46)$. There was also no correlation between $S_{275-295}$ and chl $a$ concentration. However, $S_{275-295}$ presented a significantly positive correlation with DOC, $\mathrm{pH}$, and $\mathrm{EC}$ in this plateau water $(p<0.01$, $n=46)$. Light absorption of pigments at $440 \mathrm{~nm}$ showed a significantly positive correlation with $\mathrm{TN}\left(r_{\mathrm{p}}=0.377\right.$, 
Table 3. Pearson correlation coefficients for general water quality and light absorption properties.

\begin{tabular}{lllllll}
\hline & $a_{\mathrm{CDOM}}(335)$ & $a_{\mathrm{CDOM}}(440)$ & $a_{\mathrm{PB}}(440)$ & $a_{\mathrm{phy}}(440)$ & $a_{\mathrm{NAP}}(440)$ & $S_{275-2295}$ \\
\hline TN & $0.574^{* *}$ & $0.548^{* *}$ & $0.288^{*}$ & $0.377^{* *}$ & 0.264 & 0.164 \\
TP & $0.508^{* *}$ & $0.401^{* *}$ & 0.078 & 0.194 & 0.062 & 0.151 \\
TDS & $0.483^{* *}$ & $0.534^{* *}$ & -0.048 & 0.178 & -0.068 & 0.015 \\
DOC & $0.527^{* *}$ & $0.411^{* *}$ & -0.007 & 0.151 & -0.024 & $0.377^{* *}$ \\
pH & 0.192 & 0.129 & -0.121 & 0.026 & -0.131 & $0.567^{* *}$ \\
Chl $a$ & 0.021 & 0.084 & -0.056 & 0.224 & -0.083 & 0.089 \\
TSM & 0.021 & 0.045 & $0.985^{* *}$ & $0.515^{* *}$ & $0.985^{* *}$ & -0.073 \\
EC & -0.024 & -0.083 & 0.055 & 0.081 & 0.050 & $0.506^{* *}$ \\
\hline
\end{tabular}

* $p<0.05$; ** $p<0.01$. Units of DOC, TN, TP, TDS, TSM, and DOC concentrations are $\mathrm{mg} \mathrm{L}^{-1}$; the unit of chl $a$ concentrations is $\mu \mathrm{g} \mathrm{L}^{-1}$; the $\mathrm{EC}$ unit is $\mu \mathrm{sm}^{-1}$.

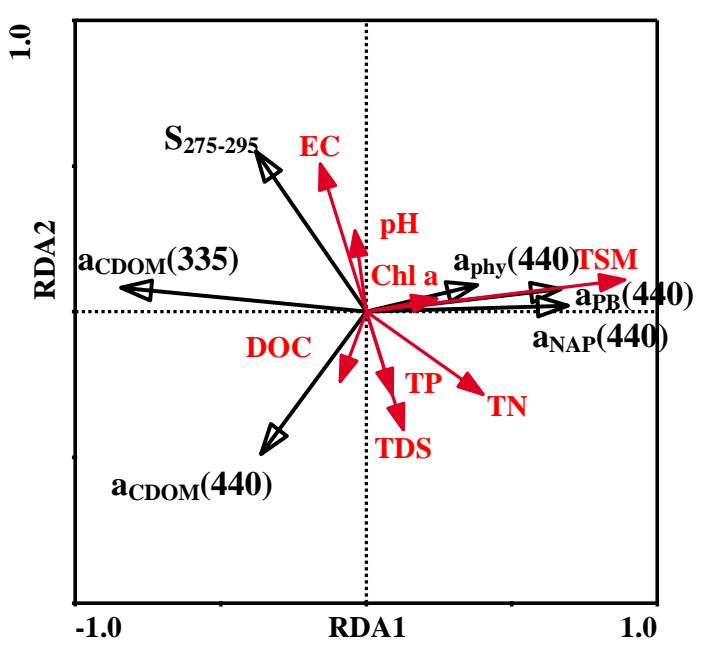

Figure 6. RDA of CDOM adsorption data and water quality parameters $(n=44)$.

$p<0.01, n=46)$ and TSM $\left(r_{\mathrm{p}}=0.515, p<0.01, n=46\right)$, and there was also no linear relationship with chl $a$ concentration. The light absorption at $440 \mathrm{~nm}$ of total particulates and non-algal particulates both had a significant positive correlation with TSM $\left(r_{\mathrm{p}}=0.985, p<0.01, n=46\right)$.

\section{Discussion}

\subsection{Dissolved organic carbon in river and terminal lakes}

Previous studies have shown that DOC concentrations in inland waters always decrease with the prolongation of water residence times due to biodegradation and photobleaching in humid regions (Curtis and Adams, 1995). However, terminal lakes with long water residence times exhibited higher DOC values than the river waters in this study. The most likely explanation for the opposite pattern of DOM concentration is that the most refractory DOC is diluted in humid regions and evapoconcentrated in semiarid regions (Song et al., 2013b). Further, the higher alkalinity and EC in the terminal lakes compared with river waters may explain the inverse pattern (Table 1). The sodicity of water could also increase DOM solubility. Increasing EC (salt concentration) would result in decreased osmotic potential, which has negative effects on microbial activity (Mavi et al., 2012). DOM, along with other nutrients, comes from soil via runoff and leaching, and can accumulate in terminal lakes due to lower microbial activity. Furthermore, the average DOC concentration in rivers $\left(25.99 \pm 6.64 \mathrm{mg} \mathrm{L}^{-1}\right)$ was higher than in many rivers reported in other studies (Alvarez-Cobelas et al., 2012; Evans et al., 2005; Findlay and Sinsabaugh, 2003; Song et al., 2013b; Spencer et al., 2010, 2012; Worrall and Burt, 2004). DOC levels in rivers are linked to climate and watershed landscape characteristics (Alvarez-Cobelas et al., 2012; Jiang et al., 2014). The elevated DOC concentrations in these plateau rivers could be attributed to evaporation, which would be expected to be extreme in the arid environment of the Inner Mongolia Plateau (Hao et al., 2007). Furthermore, the Inner Mongolia region is located in a semiarid climatic zone with low rainfall, and the impoundment of these plateau waters mainly depended on surface runoff. The land use types around the sampling locations were mainly grassland and forest (Bai et al., 2008). The high DOC concentration in the waters highlights the organic-rich nature of these ecosystems (Zheng et al., 2015).

Most monitoring data indicate that DOC concentration in rivers shows a tendency to increase year by year, potentially due to recovery from acid deposition (Evans et al., 2005; Monteith et al., 2007). DOC concentrations in surface water are depressed when acid anion concentrations are high, and increase as acidic anion concentrations decrease (Evans et al., 2005). The response of water parameters to acid deposition are apparent in the alkalinity measurements. In this study, the positive relationship between DOC and alkalinity indicated that an empirical model might be established in $\mathrm{Hu}$ lun Buir plateau waters for estimating DOC storage based on water alkalinity, with calibration by a comprehensive data set. Within semiarid regions, DOC is always related to salinity, which could reflect the water residence times and DOM 
accumulation (Curtis and Adams, 1995; Song et al., 2013b). A positive correlation between DOC and EC was established based on the collected data (Fig. $2 \mathrm{~b} ; R^{2}=0.72$ ). More than $80 \%$ of lakes in the Inner Mongolia Plateau are saline lakes, and prior research has shown that inland saline lakes always contain higher concentrations of DOC than freshwater lakes in a semiarid region (Arts et al., 2000). There are probably several reasons: saline lakes are hydrologically terminal; organic matter received and produced by saline lakes largely remains within the basin and is not exported downstream; DOC in the saline lakes accumulated with much higher rates than that in freshwaters; and saline lakes commonly support highly active biological communities, which can actively break down refractory organic matter into DOC.

The relationship between CDOM properties and nutrients (TN and TP) may be used to track the plant-derived source fraction. Strong linear relationships were shown between nutrients (TN and TP) and DOC in the surface waters (Fig. 2c and d). The types of land use around the water sampling locations may be a crucial to the nutrient levels in the waters. The main land types in the Hulun Buir plateau were grassland and forest, with high nitrogen and organic matter export rates. A similar relationship between TN and DOC was also shown during rainfall in agricultural and forested wetlands in the Shibetsu watershed, Japan (Jiang et al., 2014). Studies have indicated that DOC concentration in natural water environments is closely related to phytoplankton production and biological activity. Phytoplankton can convert dissolved inorganic carbon (mainly $\mathrm{CO}_{2}$ ) to DOM through photosynthesis, and part of the DOM in water can be degraded to $\mathrm{CO}_{2}$ by heterotrophic microorganisms. TN and TP concentrations affect the respiration and reproduction of microbes and phytoplankton, which could have a pronounced influence on the conversion between DOC and $\mathrm{CO}_{2}$. The respiration is often assumed to be conducted according to the Redfield ratio $(\mathrm{C}: \mathrm{N}: \mathrm{P}=106: 16: 1)$ under aerobic conditions (Redfield et al., 1963). When $C: N>20$ and $C: P>100$, the biodegradation of DOC cannot be fully performed. In this study, the values of $\mathrm{C}: \mathrm{N}$ and $\mathrm{C}: \mathrm{P}$ in most the of water samples satisfy the degradation condition of DOC. We suspect the above relationships (Fig. 2c and d) may be connected with the escape of $\mathrm{CO}_{2}$ from the waters. Furthermore, $\mathrm{CO}_{2}$ flux in lakes is negatively correlated with lake size (Raymond et al., 2013). If the flow and size of lakes in the study are reduced by the construction of reservoirs, irrigation, and land use, higher carbon emissions may develop. Furthermore, DOC concentration and $\mathrm{CO}_{2}$ escape from the waters are both affected by season and watershed characteristics (Organelli et al., 2014; Tranvik et al., 2009; Riera et al., 1999).

PCA was performed in order to explain the variations in water quality in the different sampling waters (Fig. 3). From the locations of the variables in Fig. 3a, PC1 could be involved in the non-water light absorption, which may be one important factor that distinguishes particulate light absorption from CDOM light absorption. TN and TP with positive loadings on PC2 indicated that PC2 may be related to anthropogenic nutrient disturbance. The close juxtaposition of TDS and chl $a$ shown in Fig. 3a indicated that TDS concentration may be linked to phytoplankton metabolism. The PCA also indicated that non-water light absorption and anthropogenic nutrient disturbance might be the causes of the diversity of water quality in different sampling locations.

The surface area of global inland waters is $3624000 \mathrm{~km}^{2}$; based on the calculation of Raymond et al. (2013), that is $2.47 \%$ of the Earth's land surface (Raymond et al., 2013). They play a substantial role in the global carbon (C) cycle, and about 2.9 $\mathrm{Pg} \mathrm{C} \mathrm{yr}^{-1}$ migrates, is transformed, and stored via the inland water ecological system (Tranvik et al., 2009). DOM is the major component of organic matter during the process of terrestrial organic matter transport to lakes and the coastal zone, and it represents an essential link between terrestrial and aquatic ecosystems (Cole et al., 2007; Harrison et al., 2005). Based on the revision of the "active pipe" hypothesis, the total current emissions from inland waters to atmosphere as $\mathrm{CO}_{2}$ and $\mathrm{CH}_{4}$ may be as high as $1.4 \mathrm{Pg} \mathrm{C} \mathrm{yr}^{-1}$, the carbon burial in inland waters sediments may amount to $0.6 \mathrm{Pg} \mathrm{C} \mathrm{yr}^{-1}$, and the annual transport from inland waters to the ocean is 0.9 Pg C (Tranvik et al., 2009). The inland waters area in the Inner Mongolian Plateau covers about $9843 \mathrm{~km}^{2}$, which is $0.27 \%$ of the global inland water surface; so a rough count in this study would be $3.8 \mathrm{Tg} \mathrm{C}$ for annual emissions, $1.6 \mathrm{Tg} \mathrm{C}$ for annual sediment burial, and $2.4 \mathrm{TgC}$ for the annual transport from Inner Mongolian Plateau inland waters. Furthermore, over $80 \%$ of lakes in Inner Mongolian Plateau are saline lakes and salt lakes. Previous studies have shown that saline lakes emit more substantial carbon to the atmosphere and contain higher DOC concentrations than freshwater (Anderson and Stedmon, 2007; Duarte et al., 2008; Osburn et al., 2011). The dissolved inorganic C concentrations are about 10-15 times greater than in freshwater lakes (Cole et al., 2011; Duarte et al., 2008; Tranvik et al., 2009). Therefore the above estimation possibly underestimated the contribution of Inner Mongolian Plateau inland waters to the global carbon cycle. The mean $\mathrm{CO}_{2}$ emission rate from saline lakes of the world is $81-105 \mathrm{mmol} \mathrm{m}^{-2}$ day $^{-1}$ (Duarte et al., 2008). When applied to the inland waters area in the Inner Mongolian Plateau of $9843 \mathrm{~km}^{2}$, the calculated $\mathrm{CO}_{2}$ emissions to the atmosphere from these inland waters amount to $3.49-4.53 \mathrm{Tg} \mathrm{C} \mathrm{yr}^{-1}$.

\subsection{Analysis of CDOM spectral characteristics}

Terminal lakes exhibited significantly higher CDOM light absorption than river waters (Table 1). Terminal lakes in the study all had high EC values $\left(>1000 \mu \mathrm{sm}^{-1}\right.$ ) (Song et al., 2013b). Researchers have reported that the structure and composition of DOM alters obviously after flowing into saline lakes (Waiser and Robarts, 2000). The use of $E_{250: 365}$ for the tracking of changes in CDOM molecule size has been practically demonstrated by many researchers (Helms et al., 
2008; Song et al., 2013b). Increasing $E_{250: 365}$ values indicate a decrease in aromaticity and molecular weight (MW) of CDOM, and the results of this study showed that CDOM in river waters had higher aromaticity and MW than terminal lakes. The relatively low CDOM MW in terminal lakes implied that chromophores associated with high MW CDOM were destroyed by photolysis with the prolongation of hydraulic retention time and irradiation. In terminal lakes, the change of molecular structure in high MW CDOM, caused by bond cleavage, resulted in its transformation to a low MW pool. Furthermore, previous studies have shown that the bulk of $E_{250: 365}$ mean values in 30 US rivers ranged from 5.00 to 6.50 (Spencer et al., 2012), and in the Elizabeth River and Chesapeake Bay estuary ranged from 4.33 to 6.23 (Helms et al., 2008). Compared with the reported river waters, the plateau rivers in the study presented significantly higher mean $E_{250: 365}$ values. The intense solar irradiance in this region potentially enhances the photochemical degradation of allochthonous DOM and high MW CDOM, causing an increase in the $E_{250: 365}$ values with the production of low MW CDOM. Two rivers in the intermontane plateaus of the western USA with intense solar irradiance also presented higher $E_{250: 365}$ values $(9.05 \pm 1.47,7.38 \pm 0.84)$ than other plain rivers (Spencer et al., 2012).

SUVA $_{254}$ values in the river waters in this study were lower than the following rivers. Mean $\mathrm{SUVA}_{254}$ values in 30 US rivers examined ranged from 1.31 to $4.56 \mathrm{~L} \mathrm{mg} \mathrm{C}^{-1} \mathrm{~m}^{-1}$ (Spencer et al., 2012), while $\mathrm{SUVA}_{254}$ in the Songnen Plain waters ranged from $2.3( \pm 0.14 \mathrm{SD})$ to 8.7 ( $\pm 2.8 \mathrm{SD}$ ) (Song et al., 2013b), and in the tropical Epulu river ranged from 3.08 to $3.57 \mathrm{~L} \mathrm{mg} \mathrm{C}^{-1} \mathrm{~m}^{-1}$ (Spencer et al., 2010). A possible driver of this CDOM characteristic in these plateau rivers is coupled evapoconcentration, photodegradation, and photobleaching, with strong plateau ultraviolet radiation (Spencer et al., 2014; Spencer et al., 2009). $\mathrm{SUVA}_{254}$ values have been proven to have a correlation with DOM aromaticity as determined by ${ }^{13} \mathrm{C}$-NMR (Weishaar et al., 2003). In this study, the lower $\mathrm{SUVA}_{254}$ measurements in terminal lakes indicated that the aromatic moieties of CDOM in this environment were lower compared within river waters due to the effect of photodegradation and microbial degradation, with prolonged water residence times. From the conclusions of some studies on $\mathrm{SUVA}_{254}$ and hydrophobic organic acid fraction (HPOA), the $\mathrm{SUVA}_{254}$ values were always comparable to HPOA, and the conjecture could be reached that low $\mathrm{SUVA}_{254}$ values indicate that the aquatic systems with little vascular plant input, and the autochthonous sources (algal or microbial) dominated the organic matter content (Spencer et al., 2008; Weishaar et al., 2003). Conversely, high $\mathrm{SUVA}_{254}$ values indicated that the organic matter in aquatic systems was dominated by allochthonous sources with significant vascular plant inputs (Cory et al., 2007; Spencer et al., 2012). In this study, the $\mathrm{SUVA}_{254}$ revealed that the contribution of vascular plant matter to DOM in rivers might be greater than the terminal lakes, and the high MW DOM was more abundant in freshwater lakes than terminal lakes. Shorter residence time of DOM in river waters and the quick exchange rates of flow water shortened the photo-oxidation of DOM, which could be responsible for the phenomenon (Song et al., 2013b; Spencer et al., 2012).

The majority of river waters in the study exhibited significantly higher $S_{275-295}$ values than allochthonous-dominated freshwaters which include the majority of US rivers (13.00$16.50 \times 10^{-3} \mathrm{~nm}^{-1}$ ) (Spencer et al., 2012), and the Congo River $\left(12.34 \times 10^{-3} \mathrm{~nm}^{-1}\right)$ (Spencer et al., 2009), which indicated the proportion of autochthonous sources of CDOM and photolysis of allochthonous CDOM in plateau waters was higher than in freshwater rivers. The ratio of spectral slopes $\left(S_{\mathrm{R}}\right)$, an indicator of CDOM molecular weight and source (Helms et al., 2008; Spencer et al., 2010), indicated that river water samples with lower $S_{\mathrm{R}}$ values contained greater allochthonous and higher MW DOM than terminal lakes. Previous studies have proven that $S$ values were inversely proportional to CDOM MW, with a steeper spectral slope signifying decreasing aromaticity, and a shallower spectral slope signifying an increasing aromatic content (Gonnelli et al., 2013; Helms et al., 2008). $S$ values in this study indicated that the percentage of high $\mathrm{MW}$ humic acid in CDOM in Hulun Lake was greater than in Buir Lake, whereas the proportion of fulvic acid and aromatic compounds showed the reverse trend. Furthermore, $S_{275-295}$ could be used as indicator for terrigenous DOC percentage in bodies of water (Gonnelli et al., 2013). Our results indicate that the percentage of terrigenous DOC is higher in Hulun Lake than Buir Lake. From the known geological history of the region, Buir Lake is a throughput lake with inflow from the Halaha River and outflow from the Wuerxun River to $\mathrm{Hu}-$ lun Lake. Also, the land use pattern in Buir Lake watersheds shows potential desertification. Hulun Lake not only receives the Wuerxun River, flowing from Buir Lake, but also receives water from the Kerulun River. Natural grassland with fresh organic rich layers was dominant in Hulun Lake watersheds. The geographical location and land use pattern together account for the larger percentage of terrigenous DOM in Hulun Lake.

\subsection{Correlations between water quality parameters and light absorption}

Strong positive correlations between CDOM absorption coefficients and TN, TP, and DOC concentrations in all water samples indicated that CDOM light absorbance could be explained by variations in nutrients and DOC concentration to a greater extent. Previous studies have shown that CDOM absorption in a range of spectra could be used as an proxy for DOC in many inland water bodies, including the Kolyma River basin (Griffin et al., 2011), the Epulu River (Spencer et al., 2010), as well as many US rivers (Spencer et al., 2012); and our results once again support this relationship in the aquatic environment of the Hulun Buir plateau. $S_{275-295}$ and 
chl $a$ concentration had no correlation; a similar phenomenon has been identified in the Ligurian Sea (BOUSSOLE site) and the Mediterranean Sea (central eastern basin) (Bracchini et al., 2010; Organelli et al., 2014). These results indicated that CDOM in natural waters did not originate entirely from the release and dissociation of the phytoplankton, and that terrestrial input and microbial activities all play an important role in the generation and properties of CDOM (Ogawa et al., 2001; Rochelle-Newall and Fisher, 2002). Furthermore, strong solar radiation in the plateau area and the open ocean enhanced the photobleaching of CDOM, resulting in variation in the structural composition of CDOM. The Inner Mongolian Plateau has high levels of wind and dust, and a number of lakes in the region have shrunk remarkably in recent decades (Tao et al., 2015). The shrinkage and resuspension of lakes as a result of climatic conditions may seriously influence the optical characteristics and chl $a$ concentration. The significant positive correlation between light absorption with TSM may be related to the unique climate of the $\mathrm{Hu}$ lun Buir plateau with alternating windy, rainless, and frigid conditions, which need to be further studied.

\subsection{Contribution of CDOM to light absorption}

At all the sampling locations, phytoplankton absorption played a minor role on total non-water light absorption (Fig. 4). The low levels of phytoplankton in the Hulun Buir plateau lakes with higher salinity may be responsible for this phenomenon. Previous studies have also shown that light absorption by non-algal particles often exceeds that of phytoplankton in shallow inland lakes and coastal waters (Carder et al., 1991; Frenette et al., 2003). In most water samples examined in this study, CDOM was the dominant lightabsorbing substance even when the CDOM absorption was minimal due to photobleaching in summer. The large contribution of CDOM to total absorption (approximately 50\% at $440 \mathrm{~nm}$ in the surface layer) was also shown in the Sepik River (Parslow et al., 1998). The large contribution of CDOM was also identified in other water environments, such as a fluvial lake (Frenette et al., 2003), the equatorial Pacific area (Bricaud et al., 2002), and the Ligurian Sea (Organelli et al., 2014). The above analysis indicated that the waters in the Hulun Buir plateau were classified as Case 2 water, with CDOM present in all the water samples (Morel and Prieur, 1977). According to Morel and Prieur (1977), Case 2 water describes the case in which non-algal particles play a major role in actual absorption, and phytoplankton absorption is of comparatively minor importance. According to the optical classification of surface waters (Prieur and Sathyendranath, 1981), the majority of the river and terminal water samples collected in the Hulun Buir plateau could be classified as "CDOM-type" water, and others were "NAP-type". Different catchment properties and water quality parameters could be responsible for the variation in optical classification of these waters. Other studies have shown that CDOM absorption is related to the EC of water (Sieczko and Peduzzi, 2014). EC values in rivers and lakes of the Hulun Buir plateau showed a wide range, which may affect the agglomeration or dissociation of particles and CDOM in the waters and indirectly influence light absorption. In addition, in lakes located near the paddy field and built-up areas, water quality is greatly influenced by human activities (Graeber et al., 2012).

The light absorption of optically active compounds (OACs) determines the inherent optical properties of waters. In our opinion, the pattern shown in Fig. 4 is not invariable, and it may change with season and some extreme climate events. First, as a constituent of DOM, CDOM inputs to lakes are a mixture of allochthonous organic substances delivered by river discharge and metabolites produced by metabolic activities of autochthonous heterotrophic bacteria (Dillon and Molot, 1997; Zhou et al., 2015). Terrestrial CDOM leached from the soil to the rivers and flowing to the lakes is subject to diverse processes: physical flocculation and adsorption, chemical photobleaching, and microbial degradation ( $\mathrm{Li}$ et al., 2014). It is widely recognized that CDOM loading and composition in aquatic environments are regulated by ambient hydrology, landscape features, climate, and aquatic organisms' activity, and vary seasonally and interannually (Dillon and Molot, 2005; Spencer et al., 2012; Worrall and Burt, 2004; Griffin et al., 2011). For example, studies have indicated that highly seasonal variability of DOC has been observed in high-latitude rivers, characterized by rising concentration significantly with increasing discharge of these rivers; spring snowmelt and winter freeze both have an effect on DOC concentration (Raymond et al., 2007). Photobleaching in summer dramatically altered the optical properties of the surface waters, with the CDOM absorption and fluorescence lost through photo-oxidation (Vodacek et al., 1997). The Hulun Buir plateau is characterized by a typical semi-humid and semiarid continental monsoon climate with intensive solar radiation (especially in summer) and a long frozen period. The temperature, snowmelt, solar radiation, water quality, and plankton and microbe activity all have a non-negligible effect on CDOM photo-absorption characteristics. Secondly, in shallow inland lakes, light absorption of non-algal particles often exceeds that of phytoplankton. The light absorption of CDOM and non-algal particles often decreases in a near-exponential manner with increasing optical wavelength, which is not beneficial for the growth of phytoplankton. In the Hulun Buir plateau, phytoplankton growth is very slow even in the warm season; the high $\mathrm{pH}$, salinity, and alkalinity of water may be responsible for this phenomenon. Therefore, the relative contributions of phytoplankton to non-light absorption in the Hulun Buir plateau may be difficult to improve due to the depressed algae growth. Non-algal particles' concentration is related to the TSM (Table 2), the sediment suspension caused by strong winds in late autumn and winter, the increase of surface runoff in spring with snowmelt, and the change of land use pattern; these factors may cause the 
increase of TSM concentration, resulting in the increase of light absorption by non-algal particles. Above all, many factors could affect the relative contributions of OACs to total non-water light absorption, and the issue should be discussed in relation to the local environment and climate.

Pareto-Lorenz curve analysis indicated that in the Hulun Buir plateau and similar geographical aquatic environments, we could randomly select $20 \%$ of the water samples collected to analyze the light absorption. The contributions of optically active substances can be estimated based on these absorption values and the cumulative contributions in this study; then the estimated value could be used to identify water type and evaluate the regional homogeneity of non-water light absorption.

\section{Conclusions}

There has been little knowledge of CDOM properties and their relationship to environmental factors in plateau areas based on previous research results. The unique environmental conditions of plateau areas with dry and cold climates have an important effect on CDOM properties and potential implications for carbon cycling in inland waters. A preliminary study was conducted in the Hulun Buir plateau which includes several freshwater rivers and numerous terminal lakes with high salinity. The study provides information on the water quality and CDOM in these rivers and terminal lakes and provides insight into CDOM properties linked to water quality characteristics. The following conclusions were obtained. (1) A significant difference in water quality was observed between rivers and terminal lakes in the Hulun Buir plateau $(p<0.01)$. The non-water light absorption and anthropogenic nutrient disturbance might be the main causes of the wide range of water quality parameters. (2) CDOM in river waters had higher aromaticity, $\mathrm{MW}$, and vascular plant contribution than in terminal lakes in cold and arid plateau regions and other freshwater rivers due to the strong evapoconcentration, intense ultraviolet irradiance, and plateau landscape features. (3) Environmental variables TSM, TN, and EC had a strong correlation with light absorption characteristics, followed by TDS and chl $a$ in the waters of the Hulun Buir plateau. A study of the optical-physicochemical correlation is helpful for evaluating the potential influence of water quality factors on non-water light absorption in arid and cold plateau water environments, and it is useful for the understanding of satellite remote sensing data of plateau inland waters.

The Supplement related to this article is available online at doi:10.5194/hess-20-787-2016-supplement.
Acknowledgements. This study was financially supported by the National Natural Science Foundation of China (no. 41171293) and the "One Hundred Talents Program" of the Chinese Academy of Sciences granted to Kaishan Song.

Edited by: M. Hipsey

\section{References}

Alvarez-Cobelas, M., Angeler, D. G., Sanchez-Carrillo, S., and Almendros, G.: A worldwide view of organic carbon export from catchments, Biogeochemistry, 107, 275-293, doi:10.1007/s10533-010-9553-z, 2012.

Anderson, N. J. and Stedmon, C. A.: The effect of evapoconcentration on dissolved organic carbon concentration and quality in lakes of SW Greenland, Freshwater Biol., 52, 280-289, doi:10.1111/j.1365-2427.2006.01688.x, 2007.

APHA/AWWA/WEF: Standard methods for the examination of water and wastewater, American Public Health Association, Washington, D.C., 1998.

Arts, M. T., Robarts, R. D., Kasai, F., Waiser, M. J., Tumber, V. P., Plante, A. J., Rai, H., and de Lange, H. J.: The attenuation of ultraviolet radiation in high dissolved organic carbon waters of wetlands and lakes on the northern Great Plains, Limnol. Oceanogr., 45, 292-299, 2000.

Bai, Y. F., Wu, J. G., Xing, Q., Pan, Q. M., Huang, J. H., Yang, D. L., and Han, X. G.: Primary production and rain use efficiency across a precipitation gradient on the Mongolia plateau, Ecology, 89, 2140-2153, doi:10.1890/07-0992.1, 2008.

Bracchini, L., Tognazzi, A., Dattilo, A., Decembrini, F., Rossi, C., and Loiselle, S.: Sensitivity analysis of CDOM spectral slope in artificial and natural samples: an application in the central eastern Mediterranean Basin, Aquat. Sci., 72, 485-498, doi:10.1007/s00027-010-0150-y, 2010.

Bricaud, A. and Stramski, D.: Spectral absorption coefficients of living phytoplankton and nonalgal biogenous matter: A comparison between the Peru upwelling area and the Sargasso Sea, Limnol. Oceanogr., 35, 562-582, 1990.

Bricaud, A., Morel, A., and Prieur, L.: Absorption by dissolved organic matter of the sea (Yekkow substance) in the UV and visible domains, Limnol. Oceanogr., 26, 43-53, 1981.

Bricaud, A., Roesler, C. S., Parslow, J. S., and Ishizaka, J.: Biooptical studies during the JGOFS-equatorial Pacific program: a contribution to the knowledge of the equatorial system, Deep-Sea Res. Pt. II, 49, 2583-2599, doi:10.1016/S0967-0645(02)000498, 2002.

Carder, K. L., Hawes, S., Baker, K., Smith, R., Steward, R., and Mitchell, B.: Reflectance model for quantifying chlorophyll a in the presence of productivity degradation products, J. Geophys. Res.-Oceans, 96, 20599-20611, 1991.

Cleveland, J. S. and Weidemann, A. D.: Quantifying absorption by aquatic particles - A multiple-scattering correction for galssfiber filters, Limnol. Oceanogr., 38, 1321-1327, 1993.

Coble, P. G.: Marine Optical Biogeochemistry: The Chemistry of Ocean Color, Chem. Rev., 107, 402-418, doi:10.1021/cr050350, 2007.

Cole, J. J., Prairie, Y. T., Caraco, N. F., McDowell, W. H., Tranvik, L. J., Striegl, R. G., Duarte, C. M., Kortelainen, P., Downing, J. 
A., Middelburg, J. J., and Melack, J.: Plumbing the global carbon cycle: Integrating inland waters into the terrestrial carbon budget, Ecosystems, 10, 171-184, doi:10.1007/s10021-006-9013-8, 2007.

Cole, J. J., Carpenter, S. R., Kitchell, J., Pace, M. L., Solomon, C. T., and Weidel, B.: Strong evidence for terrestrial support of zooplankton in small lakes based on stable isotopes of carbon, nitrogen, and hydrogen, Proc. Natl. Acad. Sci., 108, 1975-1980, doi:10.1073/pnas.1012807108, 2011.

Cory, R. M., McKnight, D. M., Chin, Y.-P., Miller, P., and Jaros, C. L.: Chemical characteristics of fulvic acids from Arctic surface waters: Microbial contributions and photochemical transformations, J. Geophys. Res.-Biogeo., 112, G04S51, doi:10.1029/2006jg000343, 2007.

Curtis, P. J. and Adams, H. E.: Dissolved organic matter quantity and quality from freshwater and saltwater lakes in east-central Alberta, Biogeochemistry, 30, 59-76, doi:10.1007/bf02181040, 1995.

De Haan, H. and De Boer, T.: Applicability of light absorbance and fluorescence as measures of concentration and molecular size of dissolved organic carbon in humic Laken Tjeukemeer, Water Res., 21, 731-734, 1987.

Dillon, P. J. and Molot, L. A.: Effect of landscape form on export of dissolved organic carbon, iron, and phosphorus from forested stream catchments, Water Resour. Res., 33, 2591-2600, doi:10.1029/97wr01921, 1997.

Dillon, P. J. and Molot, L. A.: Long-term trends in catchment export and lake retention of dissolved organic carbon, dissolved organic nitrogen, total iron, and total phosphorus: The Dorset, Ontario, study, 1978-1998, J. Geophys. Res.-Biogeo., 110, G01002, doi:10.1029/2004jg000003, 2005.

Duarte, C. M., Prairie, Y. T., Montes, C., Cole, J. J., Striegl, R., Melack, J., and Downing, J. A.: $\mathrm{CO}_{2}$ emissions from saline lakes: A global estimate of a surprisingly large flux, J. Geophys. Res.Biogeo., 113, G04041, doi:10.1029/2007jg000637, 2008.

Evans, C. D., Monteith, D. T., and Cooper, D. M.: Long-term increases in surface water dissolved organic carbon: Observations, possible causes and environmental impacts, Environ. Pollut., 137, 55-71, doi:10.1016/j.envpol.2004.12.031, 2005.

Findlay, S. E. G. and Sinsabaugh, R. L.: Aquatic Ecosystems Interactivity of Dissolved Organic Matter, Academic Press, Elsevier Science, USA, 2003.

Frenette, J. J., Arts, M. T., and Morin, J.: Spectral gradients of downwelling light in a fluvial lake (Lake SaintPierre, St-Lawrence River), Aquat. Ecol., 37, 77-85, doi:10.1023/a:1022133530244, 2003.

Gonnelli, M., Vestri, S., and Santinelli, C.: Chromophoric dissolved organic matter and microbial enzymatic activity. A biophysical approach to understand the marine carbon cycle, Biophys. Chem., 182, 79-85, doi:10.1016/j.bpc.2013.06.016, 2013.

Graeber, D., Gelbrecht, J., Pusch, M. T., Anlanger, C., and von Schiller, D.: Agriculture has changed the amount and composition of dissolved organic matter in Central European headwater streams, Sci. Total Environ., 438, 435-446, doi:10.1016/j.scitotenv.2012.08.087, 2012.

Griffin, C. G., Frey, K. E., Rogan, J., and Holmes, R. M.: Spatial and interannual variability of dissolved organic matter in the Kolyma River, East Siberia, observed using satellite imagery, J. Geophys. Res.-Biogeo., 116, G03018, doi:10.1029/2010jg001634, 2011.
Gueguen, C., Granskog, M. A., McCullough, G., and Barber, D. G.: Characterisation of colored dissolved organic matter in Hudson Bay and Hudson Strait using parallel factor analysis, J. Mar. Syst., 88, 423-433, doi:10.1016/j.jmarsys.2010.12.001, 2011.

Guo, L., Cai, Y., Belzile, C., and Macdonald, R. W.: Sources and export fluxes of inorganic and organic carbon and nutrient species from the seasonally ice-covered Yukon River, Biogeochemistry, 107, 187-206, doi:10.1007/s10533-010-9545-z, 2012.

Hao, Y., Wang, Y., Huang, X., Cui, X., Zhou, X., Wang, S., Niu, H., and Jiang, G.: Seasonal and interannual variation in water vapor and energy exchange over a typical steppe in Inner Mongolia, China, Agr. Forest Meteorol., 146, 57-69, doi:10.1016/j.agrformet.2007.05.005, 2007.

Harrison, J. A., Caraco, N., and Seitzinger, S. P.: Global patterns and sources of dissolved organic matter export to the coastal zone: Results from a spatially explicit, global model, Global Biogeochem. Cy., 19, GB4S04, doi:10.1029/2005GB002480, 2005.

Helms, J. R., Stubbins, A., Ritchie, J. D., Minor, E. C., Kieber, D. J., and Mopper, K.: Absorption spectral slopes and slope ratios as indicators of molecular weight, source, and photobleaching of chromophoric dissolved organic matter, Limnology and Oceanography, 53, 955-969, doi:10.4319/lo.2008.53.3.0955, 2008.

Jerlov, N. G.: Optical Oceanography, Oceanography Series, Elsevier, Amsterdam, 1968.

Jiang, R., Hatano, R., Zhao, Y., Kuramochi, K., Hayakawa, A., Woli, K. P., and Shimizu, M.: Factors controlling nitrogen and dissolved organic carbon exports across timescales in two watersheds with different land uses, Hydrol. Process., 28, 5105-5121, doi:10.1002/hyp.9996, 2014.

Kitidis, V., Stubbins, A. P., Uher, G., Upstill Goddard, R. C., Law, C. S., and Woodward, E. M. S.: Variability of chromophoric organic matter in surface waters of the Atlantic Ocean, Deep-Sea Res. Pt. II, 53, 1666-1684, 2006.

Kowalczuk, P. A., Stedmon, C., and Markager, S.: Modeling absorption by CDOM in the Baltic Sea from season, salinity and chlorophyll, Mar. Chem., 101, 1-11, doi:10.1016/j.marchem.2005.12.005, 2006.

Leps, J. and Smilauer, P.: Multivariate Analysis of Ecological Data using CANOCO 5, Cambridge University Press, New York, 2003.

Li, G., Liu, J., Ma, Y., Zhao, R., Hu, S., Li, Y., Wei, H., and Xie, H.: Distribution and spectral characteristics of chromophoric dissolved organic matter in a coastal bay in northern China, J. Environ. Sci., 26, 1585-1595, doi:10.1016/j.jes.2014.05.025, 2014.

Lorenz, M. O.: Methods of Measuring the Concentration of Wealth, Publ. Am. Stat. Assoc., 9, 209-219, 1905.

Mavi, M. S., Sanderman, J., Chittleborough, D. J., Cox, J. W., and Marschner, P.: Sorption of dissolved organic matter in saltaffected soils: Effect of salinity, sodicity and texture, Sci. Total Environ., 435, 337-344, doi:10.1016/j.scitotenv.2012.07.009, 2012.

Miller, W. L.: Photochemical principles and experimental considerations, Aquatic Humic Substances: Ecology and Biogeochemistry, Springer, Berlin, 1998.

Monteith, D. T., Stoddard, J. L., Evans, C. D., de Wit, H. A., Forsius, M., Hogasen, T., Wilander, A., Skjelkvale, B. L., Jeffries, D. S., Vuorenmaa, J., Keller, B., Kopacek, J., and Vesely, J.: Dissolved organic carbon trends resulting from changes 
in atmospheric deposition chemistry, Nature, 450, 537-540, doi:10.1038/nature06316, 2007.

Mopper, K. and Kieber, D. J.: Chapter 9 - Photochemistry and the Cycling of Carbon, Sulfur, Nitrogen and Phosphorus, in: Biogeochemistry of Marine Dissolved Organic Matter, edited by: Carlson, D. A. H. A., Academic Press, San Diego, 455-507, 2002.

Morel, A. and Prieur, L.: Analysis of variations in ocean color, Limnol. Oceanogr., 22, 709-722, doi:10.4319/lo.1977.22.4.0709, 1977.

Nelson, N. B. and Siegel, D. A.: The Global Distribution and Dynamics of Chromophoric Dissolved Organic Matter, Annu. Rev. Mar. Sci., 5, 447-476, doi:10.1146/annurev-marine-120710$100751,2013$.

Niu, C., Zhang, Y. L., Zhou, Y. Q., Shi, K., Liu, X. H., and Qin, B. Q.: The Potential Applications of Real-Time Monitoring of Water Quality in a Large Shallow Lake (Lake Taihu, China) Using a Chromophoric Dissolved Organic Matter Fluorescence Sensor, Sensors, 14, 11580-11594, doi:10.3390/s140711580, 2014.

Ogawa, H., Amagai, Y., Koike, I., Kaiser, K., and Benner, R.: Production of refractory dissolved organic matter by bacteria, Science, 292, 917-920, doi:10.1126/science.1057627, 2001.

Organelli, E., Bricaud, A., Antoine, D., and Matsuoka, A.: Seasonal dynamics of light absorption by chromophoric dissolved organic matter (CDOM) in the NW Mediterranean Sea (BOUSSOLE site), Deep-Sea Res. Pt. I, 91, 72-85, doi:10.1016/j.dsr.2014.05.003, 2014.

Ortega-Retuerta, E., Reche, I., Pulido-Villena, E., Agusti, S., and Duarte, C. M.: Distribution and photoreactivity of chromophoric dissolved organic matter in the Antarctic Peninsula (Southern Ocean), Mar. Chem., 118, 129-139, doi:10.1016/j.marchem.2009.11.008, 2010.

Osburn, C. L., Wigdahl, C. R., Fritz, S. C., and Saros, J. E.: Dissolved organic matter composition and photoreactivity in prairie lakes of the U.S. Great Plains, Limnol. Oceanogr., 56, 23712390, doi:10.4319/lo.2011.56.6.2371, 2011.

Para, J., Coble, P. G., Charriere, B., Tedetti, M., Fontana, C., and Sempere, R.: Fluorescence and absorption properties of chromophoric dissolved organic matter (CDOM) in coastal surface waters of the northwestern Mediterranean Sea, influence of the Rhone River, Biogeosciences, 7, 4083-4103, doi:10.5194/bg-74083-2010, 2010.

Parslow, J. S., Clementson, L. A., Turnbull, A. R., and McKenzie, D. C.: Bio-optical characteristics of oceans around Australia, Ocean optics XIV conference papers, Proceedings, Hawaii, 1998.

Phong, D. D., Lee, Y., Shin, K. H., and Hur, J.: Spatial variability in chromophoric dissolved organic matter for an artificial coastal lake (Shiwha) and the upstream catchments at two different seasons, Environ. Sci. Pollut. Res., 21, 7678-7688, doi:10.1007/s11356-014-2704-3, 2014.

Prieur, L. and Sathyendranath, S.: An optical classification of coastal and oceanic waters based on the specific spectral absorption curves of phytoplankton pigments, dissolved organic matter, and other particulate materials, Limnol. Oceanogr., 26, 671-689, 1981.

Raymond, P. A., McClelland, J. W., Holmes, R. M., Zhulidov, A. V., Mull, K., Peterson, B. J., Striegl, R. G., Aiken, G. R., and Gurtovaya, T. Y.: Flux and age of dissolved organic carbon exported to the Arctic Ocean: A carbon isotopic study of the five largest arctic rivers, Global Biogeochem. Cy., 21, GB4011, doi:10.1029/2007gb002934, 2007.

Raymond, P. A., Hartmann, J., Lauerwald, R., Sobek, S., McDonald, C., Hoover, M., Butman, D., Striegl, R., Mayorga, E., Humborg, C., Kortelainen, P., Duerr, H., Meybeck, M., Ciais, P., and Guth, P.: Global carbon dioxide emissions from inland waters, Nature, 503, 355-359, doi:10.1038/nature12760, 2013.

Redfield, A. C., Ketchum, B. H., and Richards, F. A.: The influence of organisms on the composition of sea water, Interscience Publishers, New York, 1963.

Riera, J. L., Schindler, J. E., and Kratz, T. K.: Seasonal dynamics of carbon dioxide and methane in two clear-water lakes and two bog lakes in northern Wisconsin, USA, Can. J. Fish. Aquat. Sci., 56, 265-274, doi:10.1139/cjfas-56-2-265, 1999.

Rochelle-Newall, E. J. and Fisher, T. R.: Production of chromophoric dissolved organic matter fluorescence in marine and estuarine environments: an investigation into the role of phytoplankton, Mar. Chem., 77, 7-21, doi:10.1016/s03044203(01)00072-x, 2002.

Sieczko, A. and Peduzzi, P.: Origin, enzymatic response and fate of dissolved organic matter during flood and non-flood conditions in a river-floodplain system of the Danube (Austria), Aquat. Sci., 76, 115-129, doi:10.1007/s00027-013-0318-3, 2014.

Siegel, D. A., Maritorena, S., Nelson, N. B., and Behrenfeld, M. J.: Independence and interdependencies among global ocean color properties: Reassessing the bio-optical assumption, J. Geophys. Res.-Oceans, 110, C07011, doi:10.1029/2004jc002527, 2005.

Song, K. S., Li, L., Tedesco, L. P., Li, S., Duan, H. T., Liu, D. W., Hall, B. E., Du, J., Li, Z. C., Shi, K., and Zhao, Y.: Remote estimation of chlorophyll-a in turbid inland waters: Three-band model versus GA-PLS model, Remote Sens. Environ., 136, 342357, doi:10.1016/j.rse.2013.05.017, 2013a.

Song, K. S., Zang, S. Y., Zhao, Y., Li, L., Du, J., Zhang, N. N., Wang, X. D., Shao, T. T., Guan, Y., and Liu, L.: Spatiotemporal characterization of dissolved carbon for inland waters in semi-humid/semi-arid region, China, Hydrol. Earth Syst. Sci., 17, 4269-4281, doi:10.5194/hess-17-4269-2013, 2013b.

Song, K. S., Li, L., Tedesco, L. P., Li, S., Hall, B. E., and Du, J.: Remote quantification of phycocyanin in potable water sources through an adaptive model, ISPRS J. Photogramm. Remote Sens., 95, 68-80, doi:10.1016/j.isprsjprs.2014.06.008, 2014.

Spencer, R. G. M., Aiken, G. R., Wickland, K. P., Striegl, R. G., and Hernes, P. J.: Seasonal and spatial variability in dissolved organic matter quantity and composition from the Yukon River basin, Alaska, Global Biogeochem. Cy., 22, GB4002, doi:10.1029/2008gb003231, 2008.

Spencer, R. G. M., Stubbins, A., Hernes, P. J., Baker, A., Mopper, K., Aufdenkampe, A. K., Dyda, R. Y., Mwamba, V. L., Mangangu, A. M., Wabakanghanzi, J. N., and Six, J.: Photochemical degradation of dissolved organic matter and dissolved lignin phenols from the Congo River, J. Geophys. Res.-Biogeo., 114, G03010, doi:10.1029/2009jg000968, 2009.

Spencer, R. G. M., Hernes, P. J., Ruf, R., Baker, A., Dyda, R. Y., Stubbins, A., and Six, J.: Temporal controls on dissolved organic matter and lignin biogeochemistry in a pristine tropical river, Democratic Republic of Congo, J. Geophys. Res.-Biogeo., 115, G03013, doi:10.1029/2009jg001180, 2010.

Spencer, R. G. M., Butler, K. D., and Aiken, G. R.: Dissolved organic carbon and chromophoric dissolved organic matter proper- 
ties of rivers in the USA, J. Geophys. Res.-Biogeo., 117, G03001, doi:10.1029/2011jg001928, 2012.

Spencer, R. G. M., Guo, W., Raymond, P. A., Dittmar, T., Hood, E., Fellman, J., and Stubbins, A.: Source and biolability of ancient dissolved organic matter in glacier and lake ecosystems on the Tibetan Plateau, Geochim. Cosmochim. Acta, 142, 64-74, doi:10.1016/j.gca.2014.08.006, 2014.

Stedmon, C. A., Markager, S., and Kaas, H.: Optical properties and signatures of chromophoric dissolved organic matter (CDOM) in Danish coastal waters, Estuar. Coast. Shelf Sci., 51, 267-278, doi:10.1006/ecss.2000.0645, 2000.

Tao, S., Fang, J., Zhao, X., Zhao, S., Shen, H., Hu, H., Tang, Z., Wang, Z., and Guo, Q.: Rapid loss of lakes on the Mongolian Plateau, Proc. Natl. Acad. Sci., 112, 2281-2286, doi:10.1073/pnas.1411748112, 2015.

Tranvik, L. J., Downing, J. A., Cotner, J. B., Loiselle, S. A., Striegl, R. G., Ballatore, T. J., Dillon, P., Finlay, K., Fortino, K., Knoll, L. B., Kortelainen, P. L., Kutser, T., Larsen, S., Laurion, I., Leech, D. M., McCallister, S. L., McKnight, D. M., Melack, J. M., Overholt, E., Porter, J. A., Prairie, Y., Renwick, W. H., Roland, F., Sherman, B. S., Schindler, D. W., Sobek, S., Tremblay, A., Vanni, M. J., Verschoor, A. M., von Wachenfeldt, E., and Weyhenmeyer, G. A.: Lakes and reservoirs as regulators of carbon cycling and climate, Limnol. Oceanogr., 54, 2298-2314, doi:10.4319/lo.2009.54.6_part_2.2298, 2009.

Vodacek, A., Blough, N. V., DeGrandpre, M. D., Peltzer, E. T., and Nelson, R. K.: Seasonal variation of CDOM and DOC in the Middle Atlantic Bight: Terrestrial inputs and photooxidation, Limnol. Oceanogr., 42, 674-686, 1997.

Waiser, M. J. and Robarts, R. D.: Changes in composition and reactivity of allochthonous DOM in a prairie saline lake, Limnol. Oceanogr., 45, 763-774, 2000.

Weishaar, J. L., Aiken, G. R., Bergamaschi, B. A., Fram, M. S., Fujii, R., and Mopper, K.: Evaluation of specific ultraviolet absorbance as an indicator of the chemical composition and reactivity of dissolved organic carbon, Environ. Sci. Technol., 37, 47024708, doi:10.1021/es030360x, 2003.
Worrall, F. and Burt, T.: Time series analysis of long-term river dissolved organic carbon records, Hydrol. Process., 18, 893-911, doi:10.1002/hyp.1321, 2004.

Xie, H., Aubry, C., Zhang, Y., and Song, G.: Chromophoric dissolved organic matter (CDOM) in first-year sea ice in the western Canadian Arctic, Mar. Chem., 165, 25-35, doi:10.1016/j.marchem.2014.07.007, 2014.

Yacobi, Y. Z., Alberts, J. J., Takacs, M., and Mcelvaine, M.: Absorption spectroscopy of colored dissolved organic carbon in Georgia (USA) rivers: the impact of molecular size distribution, J. Limnol., 62, 41-46, 2003.

Zhang, Y. L., Qin, B. Q., Zhang, L., Zhu, G. W., and Chen, W. M.: Spectral absorption and fluorescence of chromophoric dissolved organic matter in shallow lakes in the middle and lower reaches of the Yangtze River, J. Freshwater Ecol., 20, 451-459, doi:10.1080/02705060.2005.9664760, 2005.

Zhang, Y. L., Qin, B. Q., Zhu, G. W., Zhang, L., and Yang, L. Y.: Chromophoric dissolved organic matter (CDOM) absorption characteristics in relation to fluorescence in Lake Taihu, China, a large shallow subtropical lake, Hydrobiologia, 581, 43-52, doi:10.1007/s10750-006-0520-6, 2007.

Zhang, Y. L., Zhang, E., Yin, Y., van Dijk, M. A., Feng, L., Shi, Z., Liu, M., and Qin, B.: Characteristics and sources of chromophoric dissolved organic matter in lakes of the Yungui Plateau, China, differing in trophic state and altitude, Limnol Oceanogr., 55, 2645-2659, 2010.

Zheng, H., Gao, J., Teng, Y., Feng, C., and Tian, M.: Temporal Variations in Soil Moisture for Three Typical Vegetation Types in Inner Mongolia, Northern China, PLoS One, 10, e0118964, doi:10.1371/journal.pone.0118964, 2015.

Zhou, Y., Zhang, Y., Shi, K., Niu, C., Liu, X., and Duan, H.: Lake Taihu, a large, shallow and eutrophic aquatic ecosystem in China serves as a sink for chromophoric dissolved organic matter, J. Great Lakes Res., 41, 597-606, doi:10.1016/j.jglr.2015.03.027, 2015. 